\title{
TOURIST AND HISTORICAL FEATURES OF SETTLEMENT ON TERRITORY OF PRESENT TATARSTAN
}

\author{
Rubtzov V.A. \\ Kazan Federal University, \\ Institute of Management, Economics and Finance, \\ Kazan, 420008, Russia \\ Biktimirov N.M. \\ Kazan Federal University, \\ Institute of Management, Economics and Finance, \\ Kazan, 420008, Russia
}

\author{
Bolshanik P.V. \\ Yugra State University, \\ Khanty-Mansiysk, 628011, Russia \\ Gabdrakhmanov N.K. \\ Kazan Federal University, \\ Institute of Management, Economics and Finance, \\ Kazan, 420008, Russia
}

\author{
Safiullin N.Z. \\ Kazan Federal University, \\ Institute of Management, Economics and Finance, \\ Kazan, 420008, Russia
}

\begin{abstract}
The article shows the changes in the population on the present territory of the Republic of Tatarstan since ancient times to the end of the XIX century. The article pays special attention to the peculiarities of settlement before including the Kazan Khanate to the Russian state. It was at that time when a constant network of settlements began to emerge on the territory of present-day Tatarstan. The paper investigates the ethnic aspects of the historical and geographical settlement and identifies the main types of distribution in the region.
\end{abstract}

The distribution of population in the region depends on many factors: economic, political, transport, natural, etc., leading to an increase in internal differences in population distribution in the region. The paper quantifies the change in the average density of the Tatarstan settlements in different periods of development. The article uses the results of the 1897 census.

The study reveals regularities in the distribution of the population, which are reflected in the modern settlement system in Tatarstan.

Keywords - settling the territory, settlements network, types of population settlements, population, indigenous population.

\section{INTRODUCTION}

The multinational Republic of Tatarstan is one of the developed regions of Russia [2,6]. To date, in terms of population, Tatarstan ranks eighth among 85 subjects of the Russian Federation [3]. The region has a very rich history. It served an arena of interaction between different cultures and peoples for several centuries. The study of historical and geographical features of the settlement on the territory of Tatarstan revealed settlement regularities, whose knowledge is necessary today to ensure the sustainable development of the territory.

Settling on the territory of modern Tatarstan began since the ancient times. Despite the spontaneous emergence of settlements, their formation and placement had certain regularities caused by natural and historical conditions of settlement. They are especially seen at crucial historical periods. Such crucial periods in the history of Tatarstan were the defeat of the Bulgarian Khanate by Tatar-Mongols; the formation of the Kazan Khanate; annexation of the region to the Russian state and its colonization by the Russian people; transformation of the feudal system and the development of capitalist relations and the Great October Socialist Revolution.

\section{FINDINGS}

Prior to joining the Kazan Khanate to the Russian state semi-sedentary population, numerous devastating wars led to major changes in the permanent placement of human settlements.

Most of the Tatar villages appeared during the Kazan Khanate at the turn of the XV-XVI centuries and few of them survived on the territories of Volga Bulgaria. Cadastres and plat books of the period indicate that almost all of the settlements were located in the north-west (especially near Kazan) and Pre-Kama. 
The constant settlements network began to form only after the fall of the Kazan Khanate and its annexation to the Russian state. From the end of the XVI century, such large changes in the distribution of the settlements as in the past no longer happen. Once having appeared, settlements tend to exist in subsequent periods [8].

Intensive settling of the eastern Volga region by Tatars, Chuvash, and Mordvinians was taking place since the mid XVI century. The main reasons were progress of Russian population, the distribution of land in the estates and manors. It was also a hiding place for runaway Russian peasants and poor peasants. The huge flow of migrants was heading primarily to Trans Kama region where the land was more favorable for agriculture with its lakes and full-flowing rivers.

The number of non-Russian population that prevailed there did not lend itself to calculation. A tribute was imposed in furs and represented a category of peasants belonging to the state. Part of the Chuvash and Mari people, the so-called "podymovnye people", paid grain tribute and quitrent in Kazan. Feudal top of the non-Russian population that started to serve the Russian administration, including the newly baptized, and the service class people were endowed with the local lands. Thus, the non-Russian population of Trans Kama region was heterogeneous in its position in the system of the Russian feudal state.

The first half of the XVII century saw a rapid penetration of Russian peasant population to Trans Kama region. First of all, these were court and monastery peasants and landless peasants. They settled along the rivers and lakes, turned up the soil, setting up new settlements. The government that was interested in settling the Trans-Volga region by Russian peasants and in the development of new suitable farming areas created all the conditions for resettling the peasants there. This is clearly seen by the example of the court village Chalny.

Chalny was founded in 1626 by Yelabuga peasants on the left bank of the Kama in the estuary of Chalna. Settlers were exempt from any payment for five years, after these years a relatively small quitrent was imposed in the amount of two rubles from a taxable piece of land.

Favorable living conditions in the new location attracted a lot of people there. Chalny rapidly grew: new villages and small settlements appeared around it. By 1651 there were already 14 villages, quarters and new settlements. The population was 853 males.

Russian peasants had peaceful relations with the local nonRussian population. In close vicinity to Chalny there were villages of Bashkirs, Chuvash and Mari people which paid tributes in furs. They often shared and employed the same hay meadows and forests.

The settlement and development of new areas were uneven. Crop failures, hunger, the threat of Kalmyk attack often forced farmers to leave the inhabited lands. For example, in 1630, many Chalny farmers "fled for crop failure and for the Kalmyk people, as they were under Ufa".

A further inflow of population in the Trans-Kama region was accompanied by strengthening of feudal oppression, the expansion of feudal tenure. By the middle of the XVII century the monastic estates expanded significantly. Farmers' petitions complaining of the severity of state duties refer to that period. Documents of the middle of the XVII century mention empty yards in Chalny. Depopulation from Trans Kama region was in two directions: further migration of the population to Ufa county, and the return of part of the population back to their former places of residence.

Government policy in the Trans-Kama region refers to the period under consideration. It was characterized by a turning point in relation to court peasants, who were treated as peasants of main cities and court villages and by the increase in the number of service class people there. Several independent fortresses were built. Besides Menzelinsk fortress that existed from the end of the XVI century, Malinskiy town, Starosheshminsk and Akhtachinsk were built. Streltsy (archers) who were subsequently resettled to Trans Kama line served there.

Thus Trans Kama region by the middle of the XVII century was a mixed picture, both socially and nationally. Trans Kama region had comparatively higher population density than the rest of the territory towards the east of the Volga. Feudal estates began to develop intensively there, several strong fortresses were built, and the number of the service class people and the Russian peasant population was increasing. Trans Kama line, built in 1652-1656 completed a fortification system of the XVII century, which included Belgorod, Simbirsk and Syzranskaya fortified lines. It included wooden fortresses of Bely Yar, Erygklinsk, Tiinsk, Novosheshminsk and Zainek. In addition, it included Menzelinsky fortress and Kichuev district.

The most important feature of Trans Kama line was its emergence on the populated area, rather than on the border with the "Wild Field", as it was during the construction of the southern Russian fortifications. The line did not fully cover all the Russian lands. Beyond that there were expansive lands of Eastern Volga and Ural regions and fortified cities Ufa, Birsk, Samara, they were inhabited by people who paid tributes in furs. This geographic location of the line was due to a number of socio-economic and political factors, of which we mention the amorphous boundaries in the southeast, and the absence of large public-political organizations in the region.

Trans Kama line changed administrative boundaries of the Trans-Kama region. All the land within the line was transmitted to Kazan county. So, Chalny peasants were transferred under the authority of the governor of Kazan. The royal decree of 1652 forced line management in Kazan to concentrate.

Construction of Trans Kama fortification line and populating adjacent territories happened on the initiative of the government. By the middle of the XVII century, the Russian government had already extensive experience in the construction of the Belgorod and other fortified lines, and this experience was used in Trans Kama fortification line. Populating the region proceeded almost simultaneously with its construction. Most of the documents on resettlement of service class people refer to $1652-1653$. 
The special difficulty in settling the line was the lack of Russian service class people on its territory, which must have caused significant displacement of the population in the Kazan country. In particular, the line was mainly populated by people from fortresses on the right bank of the Volga and Kama rivers (Laish, Tetyushi, Starosheshminsk etc.), they were not needed any longer due to the construction of a fortified line.

By the end of the XVIII-early XIX centuries Tatarstan finally had the established network of settlements. Later, it underwent only minor changes, but the configuration of settlements remained relatively stable. Most fully this stable network of settlements was reflected in the list of localities in 1758 .

Before the revolution, the territory of modern Tatarstan was administratively split among the five provinces: Kazan, Vyatka, Ufa, Samara, Simbirsk. And the territory of the Kazan province accounted for 56\% of the territory of modern Tatarstan, Ufa - 19\%, Samara - 13\%, Vyatka $-8 \%$ and Simbirsk - 4\%.

According to the 10th audit in 1859 , the population on the territory of modern Tatarstan amounted to about 1.5 million people; they lived approximately in 3.2 thousand villages and 12 towns.

The bulk of the population was peasants - more than $95 \%$ of the total population. Crafts were not developed well. The total number of "industrialists" (i.e., those with some trade) made no more than 55 thousand people $(0.3 \%$ of the total population), and they lived mainly in cities.

The bulk of the population of Tatarstan was classified as the state peasants ( $76 \%$ of the total population), then landlord $(14 \%)$ and apanage $(5 \%)$ peasants followed.

Nationalities were dominated by Tatars and Russians; there were a lot of Chuvashes, Bashkirs, Mordovians and Votyaks (Udmurt). The indigenous population - the Tatars formed three main regions: 1) Zakazanie (the territory to North-West), 2) north-western part of Pre-Volga, 3) east and south-east of Tatarstan. Russian population was concentrated mainly in the cities and in the valleys of major rivers. Their share was especially great around Kazan as, according to the decree of Ivan the Terrible, Tatars were sent 50 kilometers deep into the country. Other peoples mainly lived along the borders: the Chuvash - in the south, Mari - in the north, Udmurt - in the north-east, etc. [8].

According to Vorbeva N.I., Busygin E.P., Khalikov N.A. [5], ancient settlements of Tatar, Russian, Chuvash, Mari and Udmurt people looked unconventionally, as they often repeated natural terrain, bends of a river, ravine, lake.

However, there were significant regional differences in the population size of settlements by major natural economic regions of Tatarstan.

First of all, the size of the settlements, or more precisely, the share of large settlements, sharply increased from north to south.

For example, Trans Kama region accounted for about $6 \%$ of all major settlements. This is explained by the fact that
Trans Kama region started to be populated much later than other areas, it had fertile black soil, but relatively rare river net. Therefore a small number of relatively large settlements dominated, which were the backbone of the Russian colonization of the region. In addition, in this area there was a large number of settlements - the former fortified settlements of Trans Kama defensive line.

In the era of bonded peasants with the subsistence farming and attaching the population to the soil, the populousness of settlements was influenced by the strong differences in the size of per capita allotment.

The populousness of settlements was affected by ethnic composition of certain areas. The villages with the population less than 300 people in Tatars accounted for only 14\%, while in Russians they were $43.5 \%$. The major settlements among the Tatars had the population of 500-1500 people. They accounted for $56 \%$ of all Tatar settlements, while Russians had only $31.8 \%$ of such settlements. Other nationalities also had larger settlements than Russians did - the share of the nonRussian settlements with the population of less than 300 inhabitants was only 25.85 , and larger ones (500-1500 inhabitants) - $43.7 \%$.

It should be noted that, although in general, small and medium-size settlements made more than $80 \%$ of all Russian villages, but the percentage of larger settlements (3-5 thousand inhabitants) were Russians. This is due to the fact that large settlements were once support centers of Russian colonization.

The size of settlements was influenced by natural living conditions of the population. The most is water supply. As V.N. Sementovskyi emphasized that Tatarstan, as the area of transitional forest zone to the steppe, is predominated by valley and ravine type of settlement [8]. For example, in the north-east of Tatarstan 176 of 194settlements were in the valleys, 15 - on the slopes of the valleys, and only 3 - away from them.

The average density of settlements network inTatarstan in that period was 4.8 settlements per $100 \mathrm{sq}$. $\mathrm{km}$. The maximum density was observed in the most densely populated areas and old-military regions - Pre-Volga, Pre-Kama and Northwest part. The minimum density of settlements in the South-East and the Trans-Kama region is due to the fact that the process of settlement of Tatarstan went from north to south, and at that time there were unoccupied land plots in the southern regions [9]. Furthermore, in these areas, most of the population concentrated in the large (over 1000 inhabitants) settlements, which also limited the total number.

North-East is in intermediate position between the two groups. But inside the area, the density of settlements is sharply reduced depending on the distance from the Kama River and north to south; the bulk of the settlements was concentrated on the right elevated bank of the Kama River.

Most other areas were also characterized by local concentration of settlements around the most important cities and near the Volga and Kama as well as around major tributaries. In addition, a number of linear concentrations were observed along the main roads of the region. 
After the abolition of serfdom in 1861, migratory movements intensified in the region.

Economic growth stimulated the migration of the population, its effects were seen in both the economic and social sphere. All of them are studied in a considerable number of publications on migration issues $[1,7,13]$, but there is some difficulty in getting information on migrants until they start migrating $[10,14]$. These features are particularly evident in the region studied. Migration flows allowed one to estimate the features of interethnic interaction in the region.

According to the census of 1897, 2.97 million lived on the territory of modern Tatarstan. The bulk of the population was villagers $-91.5 \%$, townspeople $-8.5 \%$, which is below the average share of the urban population in Russia as a whole [12]. Consequently, despite the abolition of serfdom, migration did not yet ensure the rapid development of cities. During the period, Tatars had particularly low migration mobility. However, even among the urban population more than half accounted for those employed in agriculture.

According to the 1897 census, as well as lists of settlements on the Volga region provinces, there were about 3150 settlements on the territory of Tatarstan, which is by 70 settlements more than now.

\section{CONCLUSIONS}

Generally, medium size settlement with population of 200500 people dominated on the territory of Tatarstan up to the middle of the XIX century and accounted for $40 \%$ of the total number of settlements. $25 \%$ of the total number of settlements was villages and hamlets with population of 500-1000 inhabitants; $16 \%$ - with population of 100-200 people. Percentage of small size settlements (less than 100 inhabitants) and large size settlements (over 1000 inhabitants) stated approximately the same - 9\% and 10\%, respectively.

1859-1897 were characterized by the polarization of the settlements. The number of small size settlements (less than 100 inhabitants) and large size settlements (over 1000 inhabitants) nearly doubled. By 1897 , the bulk of villages and hamlets of Tatarstan had constituted the settlements with 5001000 inhabitants that identifies the increase of their share and decrease of medium size settlements.

However, the distribution of the population was being increasingly intensified by the regional differences. The number of large size settlements was growing from north to south. Trans Kama region stood out in this respect as its every third village had a population of over a thousand people. The large size settlements were mostly located along the rivers and valleys. It was the north-eastern region where the proportion of settlements with population of more than 500 inhabitants reached $92.5 \%$ (all the settlements were located along the river).

Moreover, Tatarstan, particularly northern regions, has a watershed (syrt) type settlement. But usually, the settlements of this type used to be of small size and with sparse network due to limited water supply. Thus, a number of small size settlements were situated in ravines and hollows.

The river nature of the network formation was not the only condition determining the present shape of settlements distribution, quality of soil and the presence of flat areas (wastelands, burning, forest clearing) affected the size of the settlements as well. Thus, ceteris paribus, the settlements placed on the more fertile black soils had higher growth rates and were much larger in size.

The transport factor also had a great influence on the population of Tatarstan settlements. Rivers, valleys had not only physical and geographical values but served as natural transport routes. This was the way by which mostly Russians occupied the territory.

The introduction and development of river transport stimulated the emergence of large size settlements along the rivers. The new types of settlements appeared on the docks: office and residential settlements in the backwaters and nearby ship-repair yards (Derbyshki, Kuibyshev backwater, Arakchino at river crossings Tatar Burnashevo). The small size settlements arose in the valleys of small rivers that flow into the Volga and the Kama.

The development of commodity exchange and the territorial division of labor led to appearance of a relatively well-developed network of commercial and postal roads. Mainly medium and large size settlements with population of not less than 500 inhabitants were located along them.

The greatest influence on the emergence of large size settlements had the construction of Moscow-Kazan railway (1891-1893). That initiated the growth of settlements network along it, e.g. nearby locomotive depot, around railway works (Yudino) and major stations (Lagernaya), etc.

The development of industrial production, especially flour, affected proliferation of large villages in the vicinity of the major mills and elevators (Pechischi, Berezhnye Chelny).

A number of large size settlements in Tatarstan were located in the field of oil and minerals extraction.

The total "picture' of settlement network of that time was represented by a combination of stable territorial settlements almost evenly placed on the territory.

\section{Acknowledgement}

The research was performed with the financial support of the Russian Fund of Fundamental Research; the project "The forecast of social and economic development of rural settlements in the Republic of Tatarstan”, №17-12-16005.

\section{References}

[1] B. Anderson, Nations, migration and domestic labor: The case of the UK. Women's Studies International Forum, no. 46, 2014, pp. 5-12.

[2] N. Biktimirov, N. Gabdrakhmanov, V. Rubtsov, M. Mustaphin, N. Arzhantseva, Peculiar Features of the Tatar People Migration on the Territory of Tatarstan, Mediterranean Journal of Social Sciences, Vol 5, No 24, 2014, pp. 267-272. 
[3] R. Denmukhametov, O. Zjablova, Geodemographic Situation in the Republic of Tatarstan, World Applied Sciences Journal, 2014, no. 30 (11), pp. 1684-1688.

[4] N.K. Gabdrakhmanov, L.N. Safiullin, Role of historical cities in the tourist breading (case study of republic of Tatarstan), Academy of Marketing Studies Journal, Vol. 20, 2016, pp.135-143.

[5] I. Gaisin, N. Biktimirov, Migration Processes in the Republic Tatarstan in the Second Half of the 20th and in the Early of 21st Centuries: Ethnic and Social Aspects, Middle-East Journal of Scientific Research, no. 20(12), 17611766, 2014.

[6] F. Kharisova, I. Kosova, Some questions of IT control in economic entities, International Business Management, 2016, no. 10, pp. 51135120.

[7] H. Kulu, T. Washbrook, Residential context, migration and fertility in a modern urban society Advances in Life Course Research, no. 21, 2014, pp. $168-182$.

[8] M.R. Mustafin, New trends in the distribution of the population in Tatarstan. Kazan, 1990.

[9] G.I. Peretyakovich, Povolzhe v XVII i v nachale XVIII v. Ocherki iz istorii Nizovya» (Volga region at the edge of XVII- XVIII centuries. Study on history of lower reaches of the Volga river), Doctoral thesis, 1882.

[10] G. Prayitno, K. Matsushima, H. Jeong, K. Kobayashi, Social Capital and Migration in Rural Area Development, Procedia Environmental Sciences, no. 20, 2014, pp. $543-552$.

[11] V.A. Rubtzov, M.V. Rozhko, N.K. Gabdrakhmanov, A.A. Gilmanova, Competitiveness and positioning of municipalities in the republic of Tatarstan, Mediterranean Journal of Social Sciences, no. 6(3), pp. 761765.

[12] Semenov-Tyan-Shanskiy, V.Gorod i derevnya v evropeyskoy Rossii: ocherk po ekonomicheskoy geografii (City and village on the European part of Russia: a study on economic geography), SPb.: V. F. Kirshbauma Publishing House, SPb.

[13] L. Yanyan, Futoshi Yamauchi Population density, migration, and the returns to human capital and land, Insights from Indonesia, Food Policy, no. 48,2014 , pp. 182-193.

[14] A. Yija"la", I. Jasinskaja - Lahti, Pre-migration acculturation attitudes among potential ethnic migrants from Russia to Finland, International Journal of Intercultural Relations, no. 34, 2010, pp. 326-339. 